\title{
Filip Palda: In memoriam
}

\author{
Alexandre Couture Gagnon ${ }^{1}$ (D)
}

Received: 13 January 2018/Accepted: 18 January 2018/Published online: 30 January 2018

(C) Springer Science+Business Media, LLC, part of Springer Nature 2018

Filip Palda, an economist, frequent Public Choice contributor, and specialist in electoral rules and tax policy, died on August 24, 2017. He was a faculty member at the École nationale d'administration publique (ENAP) in Québec and Senior Fellow at the Fraser Institute until his death. Palda's contributions to economics and public choice are well known to the readers of Public Choice. Here and elsewhere, he argued that campaign spending limits act as barriers to entry into the political arena, and elaborated on the deadweight welfare loss resulting from tax evasion. He also embraced the role of public intellectual and contrarian, seeking to popularize public choice concepts, notably in Québec.

Palda completed his Ph.D. at the University of Chicago in 1989 under the supervision of Gary Becker, 1992 Nobel Laureate in Economics. Palda then worked at the University of Ottawa, at the Fraser Institute and at the ENAP in Québec, where he became Full Professor in 2002. In 1993-2002, Palda ranked sixth as the author with the most pages (90) in Public Choice (Sobel and Taylor 2004). He published nine articles in the journal. Overall, he published more than 25 journal articles, eight monographs, six edited books, and hundreds of newspaper and magazine articles (Palda 2011).

Palda published his first academic paper in Public Choice, in 1985, while a graduate student at Queen's University, Canada (Palda and Palda 1985). His 1985 article, coauthored with his father Kristian Palda, is emblematic of the research path he took in the 1980s and 1990s, on the barriers to entry caused by electoral campaign spending limits. ${ }^{1}$ The article demonstrated that limiting campaign expenditures benefits incumbents over

\footnotetext{
1 At the beginning of many of his books, Filip Palda introduces his father's life as foundational to his own intellectual development. Kristian Palda left Czechoslovakia after the Nazis had destroyed his country and communists threatened to arrest him. He is Professor Emeritus at Queen's University in Canada. His work on advertising in elections and votes clearly influenced Filip Palda.
}

Alexandre Couture Gagnon

alexandre.couturegagnon@utrgv.edu

1 Department of Public Affairs and Security Studies, The University of Texas Rio Grande Valley (UTRGV), 1 West University Boulevard, Brownsville, TX 78520, USA 
challengers. Palda later published on the link between contributions and spending in election campaigns (Palda 1992), and expanded his findings in the book How much is your vote worth? The unfairness of campaign spending limits (Palda 1994). In another Public Choice article opposing campaign spending limits, written with his father and using data from the 1993 French elections, Palda wrote that "Incumbent candidates can at best expect to win $1.01 \%$ of the popular vote for each extra franc they spend per registered voter in their district. Challengers can expect to win at least twice as much as this" (Palda and Palda 1998, p. 157). Again, in Public Choice, Dharmapala and Palda (2002) challenged the assumptions behind the 1976 US Supreme Court decision in Buckley v. Valeo, on the link between money in political campaigns and votes. They showed that, in US House elections from 1980 to 1992, for open seats and challengers, the concentration of money contributions was negatively related to votes. In other words, it seemed that voters did not like challengers and open seat candidates who ran their campaigns on concentrated contributions; the relation was "insignificant or weakly positive" for incumbents. Later, and also in Public Choice, Palda and I demonstrated that reporting requirements imposed on independent citizens' groups in Canadian federal elections act as a barrier to entry into political discussions and cost some 9\% of those groups' budgets (Couture Gagnon and Palda 2011).

A second research path for Palda was to contribute to the understanding of the deadweight social welfare loss associated with public policies. In 1998, he published a theoretical article on deadweight losses stemming from smaller, inefficient firms' ability to evade taxes. In that paper, the example Palda used to explain the concept is particularly memorable:

Large wholesalers of cut flowers in the Czech Republic have complained that they run more efficient businesses than their smaller rivals (in part owing to scale economies in refrigeration and transport of flowers), but that their profits are lower. The small rivals even risk putting the efficient wholesalers out of business. The source of the small rivals' advantage is that they are willing to smuggle cut flowers from Holland across the Czech border in small, unrefrigerated trucks in which wastage is high, while large wholesalers pay to bring their stock over in easily spotted refrigerated trucks. If tax-evading flower sellers manage to put large wholesalers out of business, a group of many small, high-cost merchants will have replaced a few efficient merchants. The difference in production costs between the inefficient and efficient merchants is the efficiency cost from the interaction of the underground economy and the tax system. (Palda 1998a p. 1119).

In the same vein, Palda (2000b, p. 751) focused on "the deadweight loss that society bears when high reservation-cost workers displace low reservation-cost workers". He summarized the policy implication: "When firms can evade part or all of the minimum wage, an extra deadweight loss arises. Firms with high evasive ability but low productivity may displace firms with low evasive ability but high productivity" (Palda 2000a, b, p. 751).

In the 2000s, Hanousek and Palda (both affiliated with the Center for Economic Research and Graduate Education-Economics Institute in Prague, Czech Republic) published seven articles and papers on tax evasion and displacement deadweight losses, notably using survey data from the Czech Republic. Hanousek and Palda (2002, 2006a) first studied the determinants of tax evasion (pinpointing rising incomes) by comparing the Czech and Slovak Republics, and then estimated parameters determining tax evasion in the Czech Republic from 2000 to 2004 (predicting a reduction in the following years). They then found that "citizens will avoid taxes if they do not believe they are getting quality government services for the taxes levied upon them" (Hanousek and Palda 2004, p. 237). 
Afterwards, the two authors discussed how difficult it is to estimate tax evasion in transition economies using traditional measures of money and electricity demands, with the Czech Republic as a case study (Hanousek and Palda 2005, 2006b). They showed the existence of an "evasional Kuznets curve" during the Czech Republic's transition to a more market-oriented economy and demonstrated displacement deadweight loss (Hanousek and Palda 2008). Finally, Hanousek and Palda estimated the displacement deadweight loss in the Czech Republic at "2.7-13.1\% of industry costs" (Hanousek and Palda 2009, p. 142).

Also on deadweight loss, in Public Choice, Palda built on Buchanan's three "traditional costs associated with rent-seeking," proposing a fourth cost (Palda 2000a). Palda deduced that the "deadweight loss from the improper selection of high cost firms (called here 'selection costs') may have to be added to the traditional costs associated with rent-seeking to guage [sic] the total deadweight losses from political contest" (Palda 2000a, p. 292). In the article's conclusion, Palda explains how this novel cost has implications for national economic growth.

Palda was eclectic, too curious to play it safe and stick to one niche area of research. He published on many topics throughout his career. Matsusaka and Palda (1993) demonstrated in Public Choice that the rational voter model did not fully apply in the 1979 and 1980 Canadian elections. Also in Public Choice, Palda (1993) argued theoretically that foreign aid to less developed countries needs more than strict constraints to promote growth. To summarize in a few words, the foreign leader's utility must be taken into account by the donor. Later, Palda (1997) built a model of political efficiency and tested potential fiscal churning in Canada. Once more, in Public Choice, Matsusaka and Palda (1999) found that the determinants of voter turnout are hard to pinpoint for Canadian elections from 1979 to 1988. That same year, Palda (1999), in Public Choice, built a model that reconciled two theories of national wealth: redistribution of income and securing of property rights. He argued that the former, in "small amount," can increase national wealth if the latter are in place.

Palda was interested in popularizing advanced public choice concepts and expanding the audience for his scholarly output. One avenue to achieve that goal was his work as a Senior Fellow at the Fraser Institute, a think tank that promotes public choice ideas in Canada. He published many books with the Fraser Institute. Home on the Urban Range (Palda 1998b), for example, proposes policy tools to increase efficiency at the local level. It is easy to read and full of well-informed examples. He made friends at the Fraser Institute, including Zane Spindler, about whom he later (2014) co-edited a book with Xavier de Vanssay (De Vanssay and Palda 2014).

Palda's final books were geared to sharing public choice concepts with the more general public. Pareto's Republic presented economic efficiency as a cornerstone of social accounting, which Palda described as "the kind of accounting that creates balance between the efforts people make and the benefits they receive," hence providing the recipe for a peaceful society (Palda 2011, p. 1). He divided the book into chapters, understandable on their own, on property rights, the rationale for government intervention, deadweight losses from taxation, political competition and a prospective chapter on international migration as a way of achieving Pareto efficiency. The Apprentice Economist (Palda 2013) distills economics and public choice concepts for laypersons. The central argument is the relation between social cohesion and Pareto efficiency, with a focus on the most important supporting ideas. The book is divided into seven chapters, each presenting multiple concepts under one theme, with references to the history of economics and original examples. Palda mastered the construction of chapter-length explanations of core concepts such as present 
value, game theory, and the basics of statistical analysis, without graphs or ominous tables! In the book, Palda was unapologetic about the complexity of the science of economics. Yet he also explained why it is the best field of scholarship to inform social peace and kept the tone fit for a large audience. In the Preface, Palda wrote:

A clear and quantifiable idea of the basis of social cohesion is why economics remain the only guide which the mass, anonymous societies of today can use to avoid blundering into depression and even chaos. Economists who think their topic is a tapdance should seek a calling in the entertainment industry. Economics is a noble undertaking in which there is no place for the intellectual kibitzer, the gag-artist, the purveyor of trivia. If such solemnity strikes you as being excessive, think of 'Boozey Barley' Blair in John LeCarré's The Russia House explaining in his cups that 'today you have to think like a hero to be a merely decent human being'. (Palda 2013, p. 3)

Palda's last book, A Better Kind of Violence (2016) — lovingly dedicated to his wifeoffered historical descriptions of both Chicago political economy and public choice as theories of power. While the former concludes that we tend towards efficiency because we seek to maximize our wellbeing, the latter focuses on the median voter theorem. Palda used that distinction to introduce a possible third field, mechanism design. Palda referred to the Vickrey-Clarke-Groves auction, where people choose between alternatives through an auction and the "pivotal" voter of the winning alternative compensates the losers. Palda admitted that mechanism design is hard to implement politically, but nonetheless saw hope through it for a reconciliation of Chicago political economy and public choice.

I like to think that Palda succeeded in making public choice concepts more palatable to the general public. After his death, a commentator on Canada's French public broadcasting radio ICI Radio-Canada, mentioned how sad he was about Palda's departure, for his ideas. Few economists touch minds outside of academia enough to be remembered in a popular primetime radio show (ICI Radio-Canada 2017). He was Québec's most famous public choice economist. He popularized his research on campaign regulations and efficiency in French books (e.g., Boucher and Palda 2000) and French book chapters (Palda 2010; Couture Gagnon et al. 2014). He gave many interviews and commented on multiple topics related to economics. In a province where the government is celebrated for saving the population from the Catholic Church's ubiquity (until the Quiet Revolution of the 1960s), and replacing it in the provision of welfare, education and healthcare services, Palda's explanations of public choice appeared strange and controversial. His public choice vision invited people to reflect on government interventions and engaged them in a different perspective on how society should work. Many scholars might take such popular media interviews lightly, but Palda prepared with great care and appreciated opposition from other commentators as an opportunity to better explain his concepts.

Palda was my M.Sc. supervisor at the École nationale d'administration publique from 2005 to 2007. I admired how he encouraged me to think creatively. He seemed interested in everything. I remember our conversations about other countries, about my experiences as a student and how fascinating everything seemed to him. A few years later, then a Ph.D. student, I presented joint work on our behalf at a prestigious conference. Palda's advice before I went displayed his guileless curiosity: take in all comments, especially those that seem to make no sense-they could have the most interesting angle. 


\section{References}

Boucher, M., \& Palda, F. (2000). Ici, le peuple gouverne: Pour une réforme de la démocratie. Montréal: Les Éditions Varia.

Couture Gagnon, A., Francis, O. Y., \& Palda, F. (2014). Politique d'immigration au Québec: Un futur fondé sur le marché. In Robert Bernier (Ed.), Les défis québécois: Conjonctures et transitions. Québec: Presses de l'Université du Québec.

Couture Gagnon, A., \& Palda, F. (2011). The price of transparency: Do campaign finance disclosure laws discourage political participation by citizens' groups? Public Choice, 146(3-4), 353-374.

De Vanssay, X., \& Palda, F. (Eds.). (2014). Socratic economist: Reflections on the life and writings of Zane Spindler. Kingston: Cooper-Wolfling.

Dharmapala, D., \& Palda, F. (2002). Are campaign contributions a form of speech? Evidence from recent US House elections. Public Choice, 112(1), 81-114.

Hanousek, J., \& Palda, F. (2002). Why people evade taxes in the Czech and Slovak Republics: A tale of twins. CERGE-EI Discussion Paper, Prague.

Hanousek, J., \& Palda, F. (2004). Quality of government services and the civic duty to pay taxes in the Czech and Slovak Republics, and other transition countries. Kyklos, 57(2), 237-252.

Hanousek, J., \& Palda, F. (2005). Measuring the informal sector in a transition economy using macro methods: New evidence. CERGE-EI Discussion Paper, Prague.

Hanousek, J., \& Palda, F. (2006a). Estimating the evolution of tax evasion: A Markov chain analysis applied to the Czech Republic. Czech Journal of Economics and Finance, 56(3-4), 127-151.

Hanousek, J., \& Palda, F. (2006b). Problems measuring the underground economy in transition. Economics of Transition, 14(4), 707-718.

Hanousek, J., \& Palda, F. (2008). Tax evasion dynamics in the Czech Republic: First evidence of an evasional Kuznets curve. Prague: CERGE-EI.

Hanousek, J., \& Palda, F. (2009). Is there a displacement deadweight loss from tax evasion? Estimates using firm surveys from the Czech Republic. Economic Change and Restructuring, 42(3), 139-158.

ICI Radio-Canada. (2017). Médium large. September 1st. 9 to 11:30 a.m.

Matsusaka, J. G., \& Palda, F. (1993). The Downsian voter meets the ecological fallacy. Public Choice, 77(4), 855-878.

Matsusaka, J. G., \& Palda, F. (1999). Voter turnout: How much can we explain? Public Choice, 98(3-4), 431-446.

Palda, F. (1992). The determinants of campaign spending: The role of the government jackpot. Economic Inquiry, 30(4), 627-638.

Palda, F. (1993). Can repressive regimes be moderated through foreign aid? Public Choice, 77(3), 535-550.

Palda, F. (1994). How much is your vote worth? The unfairness of campaign spending limits. San Francisco: Institute for Contemporary Studies.

Palda, F. (1997). Fiscal churning and political efficiency. Kyklos, 50(2), 189-206.

Palda, F. (1998a). Evasive ability and the efficiency cost of the underground economy. Canadian Journal of Economics, 31(5), 1118-1138.

Palda, F. (1998b). Home on the urban range: An idea map for reforming the city. Vancouver: The Fraser Institute.

Palda, F. (1999). Property rights vs. redistribution: Which path to national wealth? Public Choice, 101(1), $129-145$.

Palda, F. (2000a). Improper selection of high-cost producers in the rent-seeking contest. Public Choice, 105(3-4), 291-301.

Palda, F. (2000b). Some deadweight losses from the minimum wage: The cases of full and partial compliance. Labour Economics, 7(6), 751-783.

Palda, F. (2010). L'arsenal de la démocratie: Perspectives de changement au Canada et dans les provinces. In Robert Bernier (Ed.), L'espace canadien: Mythes et réalités, une perspective québécoise. Québec: Presses de l'Université du Québec.

Palda, F. (2011). Pareto's Republic and the new science of peace. Kingston: Cooper-Wolfling.

Palda, F. (2013). The apprentice economist. Kingston: Cooper-Wolfling.

Palda, F. (2016). A better kind of violence. Kingston: Cooper-Wolfling.

Palda, K. F., \& Palda, K. S. (1985). Ceilings on campaign spending: Hypothesis and partial test with Canadian data. Public Choice, 45(3), 313-331.

Palda, F., \& Palda, K. (1998). The impact of campaign expenditures on political competition in the French legislative elections of 1993. Public Choice, 94(1), 157-174.

Sobel, R. S., \& Taylor, J. J. (2004). The last 30 years of Public Choice: An analysis of author and institution rankings. Public Choice, 120(3-4), 331-352. 